\title{
Survei Keterampilan Berpikir Kritis Mahasiswa pada Materi Usaha dan Energi
}

\author{
Sujiyani Kassiavera ${ }^{1}$, A Suparmi ${ }^{2}, \mathrm{C} \mathrm{Cari}^{3}, \mathrm{~S} \mathrm{Sukarmin}^{4}$ \\ ${ }^{1}$ Program Studi Doktor Pendidikan IPA Universitas Sebelas Maret Surakarta \\ 2,3 Program Studi Ilmu Fisika Pascasarjana Universitas Sebelas Maret Surakarta \\ ${ }^{4}$ Program Studi Pendidikan Fisika Pascasarjana Universitas Sebelas Maret Surakarta \\ J1. Ir. Sutami 36A Kentingan Jebres Surakarta 57126, INDONESIA \\ Email : sujiyani.kassiavera@student.uns.ac.id/sujiyani.kassiavera@gmail.com
}

\begin{abstract}
This study aims to determine the critical thinking skills possessed by students. The Subject of this research were 131 students of physics education program from Bengkulu University and Indraprasta University. Subjects consist of $4^{\text {th }}$ semester (56 students) and $6^{\text {th }}$ semester (75 students) who have received the Basic Physics course previously. Instrument of this research using test concept. Based on the results of a survey conducted that students' critical thinking skills are still very low on business work- energy. This survey research will be the main basis for researchers to conduct further research with the same research location.
\end{abstract}

Keywords: Critical thingking skill, Work-Energy

\begin{abstract}
Abstrak: Penelitian ini bertujuan untuk mengetahui keterampilan berpikir kritis yang dimiliki mahasiswa. Subjek penelitian ini adalah 131 mahasiswa yang terdiri dari semester 4 (56 siswa) dan semester 6 (75 siswa) yang telah menerima materi Fisika Dasar sebelumnya. Teknik pengumpulan data menggunakan metode tes. Berdasarkan hasil survei yang dilakukan bahwa keterampilan berpikir kritis mahasiswa masih sangat rendah pada materi usaha dan energi. Penelitian survei ini akan menjadi dasar utama bagi peneliti untuk melakukan penelitian lanjutan dengan lokasi penelitian yang sama.
\end{abstract}

Kata kunci: Keterampilan Berpikir Kritis, Usaha dan Energi

\section{PENDAHULUAN}

Taksonomi bloom mengklasifikasikan enam proses kognitif apakah siswa mampu atau belajar untuk mengingat (C1), memahami (C2), mengaplikasikan (C3), menganalisis (C4), mengevaluasi (C5), dan mengkreasi (C6) (Anderson \& Krathwohl \&, 2001). Berpikir kritis termasuk dalam ranah kognitif tipe C4-C6 yang merupakan bagian penting dalam kemampuan berpikir tingkat tinggi. Keterampilan berpikir kritis sangat dibutuhkan untuk keberhasilan pada abad 21 (Pellegrino, 2017). Keterampilan berpikir kritis terdapat enam aspek yaitu interpretation, analysis, evaluation, inference, explanation, dan self-regulation (Facione, 1990). Taksonomi bloom mengasumsikan keberlanjutan yang mendasari proses kognitif menjadi lebih kompleks terutama dalam pembelajaran IPA (Winarti, 2015).

Pembelajaran IPA merupakan pembelajaran tentang suatu kumpulan pengetahuaan yang tersusun secara sistematis dan dalam penggunaannya secara umum terbatas pada gejala-gejala alam (Trianto, 2010). Fenomena gejala alam menjadi rangkaian dalam kehidupan sehari-hari untuk memenuhi kebutuhan manusia melalui pemecahan masalah-masalah yang dapat diidentifikasikan (Rahayu, 2014). Fenomena ini sering terjadi pada pembelajaran fisika terutama pada materi usaha dan energi.

Tujuan dari peneltian ini adalah melihat tingkat keterampilan berpikir kritis mahasiswa pada materi usaha dan energi. Usaha-energi merupakan bagian dari mekanika klasik yang 
mengkaji pergerakan suatu benda dari posisi awal hingga akhir, serta penyebab gerakan benda (Rahmatina, et al., 2017). Usaha dan energi merupakan salah satu konsep dasar dan terpenting yang perlu dipelajari dalam fisika (Manjarres et al., 2013).

\section{METODE}

Penelitian ini dilakukan pada mahasiswa program pendidikan fisika dari Universitas Bengkulu dan Universitas Indraprasta. Subjek penelitian ini adalah 131 mahasiswa yang terdiri dari semester 4 (56 mahasiswa) dan semester 6 (75 mahasiswa) yang telah menerima materi Fisika Dasar sebelumnya. Subjek ditentukan dengan menggunakan teknik random sampling. Metode pengumpulan data dalam penelitian ini menggunakan metode tes. Teknik pengumpulan data yang digunakan adalah tes dengan instrumen yang terdiri dari 12 pertanyaan yang telah divalidasi oleh ahli materi. Penelitian dari survei ini dikelompokkan berdasarkan komponen kemampuan berpikir kritis dalam setiap pertanyaan yang sebelumnya dibuat pemetaan konsep berdasarkan sub-materi. Dapat dilihat pada tabel 1 dan tabel 2.

Tabel 1. Sub-Materi pada Konsep Usaha dan Energi

\begin{tabular}{lc}
\hline \multicolumn{1}{c}{ Sub-Materi } & Item \\
\hline Usaha & $1,2,7,11$ \\
Energi Kinetik & 12,6 \\
Gaya konservatif dan Nonkonservatif & 9 \\
Hukum Kekekalan Energi Mekanik & $3,4,5$ \\
Gaya Pegas & 8,10 \\
\hline
\end{tabular}

Tabel 2. Komponen Keterampilan Berpikir Kritis

\begin{tabular}{lc}
\hline \multicolumn{1}{c}{$\begin{array}{c}\text { Keterampilan Berpikir } \\
\text { Kritis }\end{array}$} & Item \\
\hline Interpretation & 2,7 \\
Analysis & 6,11 \\
Inference & 1,10 \\
Explanation & 3,4 \\
Evaluation & 8,9 \\
Self Regulation & 5,12 \\
\hline
\end{tabular}

\section{HASIL DAN PEMBAHASAN}

Data yang diperoleh dari penelitian suvei ini berupa hasil diagnosis jawaban benar mahasiswa yang telah menerima materi usaha dan energi (telah menempuh mata kuliah Fisika dasar pada semester sebelumnya. Data yang diperoleh dinyatakan dalam presentase jawaban benar untuk setiap komponen kemampuan berpikir kritis yang disajikan pada gambar 1 . Ratarata skor keseluruhan dari tes yang telah dilakukan adalah sebesar 37,1\%. Pada Gambar 1 . Ditunjukkan bahwa mahasiswa yang dijadikan sampel memiliki persentase skor rata-rata terendah pada komponen Analysis yang terdiri dari pertanyaan nomor 6 dan 11 sebesar $22,5 \%$. Sedangkan untuk perolehan rata-rata tertinggi untuk jawaban benar diperoleh pada komponen Interpretation yaitu sebesar 54,6\%. 


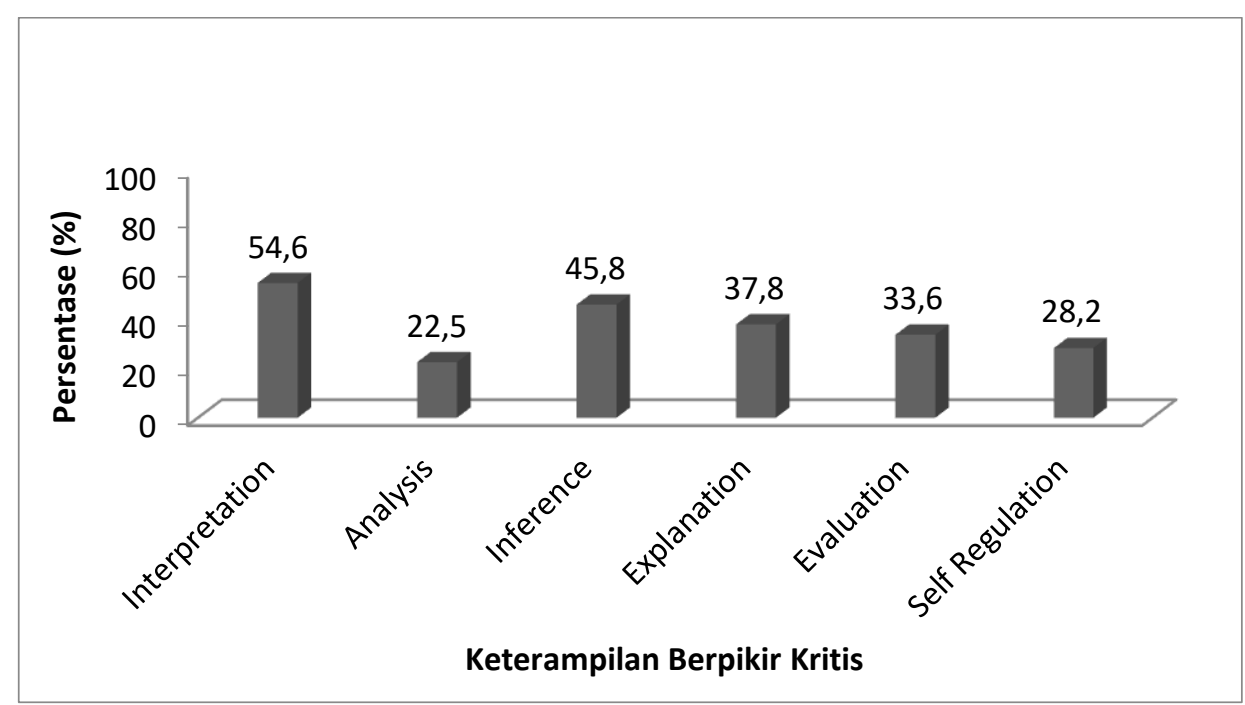

Gambar 1. Diagram keterampilan berpikir kritis

Berdasarkan Gambar 1. Terlihat bahwa pada komponen Interpretation diperoleh rata-rata skor sebesar 54,6\%. Perolehan persentase skor rata-rata ini merupakan skor rata-rata tertinggi dari seluruh komponen kemampuan berpikir kritis yang digunakan dalam pertanyaan. Persentase jumlah mahasiswa yang menjawab benar pada komponen Interpretation ini diperoleh pada pertanyaan nomor 2 yaitu sebanyak 103 mahasiswa $(78,6 \%)$. Sedangkan pada pertanyaan nomor 7 dijawab benar dengan persentase $30,5 \%$.

Pada komponen Inference diperoleh skor rata-rata sebesar 45,8\%. Untuk komponen ini pertanyaan nomor 1 merupakan pertanyaan yang paling banyak dijawab benar oleh mahasiswa yaitu sebanyak 94 mahasiswa (71,7\%). Sedangkan pada komponen Explanation diperoleh skor rata-rata lebih kecil dibandingkan pada komponen sebelumnya dengan perolehan sebesar 37,8\%. Begitu pula pada komponen ini mahasiswa banyak menjawab benar pada soal nomor 4 yaitu dengan nilai rata-rata sebesar $64,1 \%$. Untuk komponen self regulation memperoleh persentase skor rata-rata sebesar $28,2 \%$. Nilai yang diperoleh ini juga termasuk pada kategori rendah. Pada komponen ini mahasiswa yang menjawab benar hanya pada nomor 5 yaitu sebanyak 49 mahasiswa (37,4\%). Dengan kata lain hasil ini menunjukkan bahwa tingkat keterampilan berpikir kritis mahasiswa masih sangat rendah. Oleh karena itu, Kecenderungan siswa untuk berpikir kritis adalah prasyarat yang diperlukan untuk berpikir kritis, dan itu sangat mempengaruhi kemampuan berpikir kritis (Demirhan \& Köklükaya, 2013)

Hal ini menunjukkan bahwa materi usaha dan energi masih dianggap sulit oleh mahasiswa. (Lawson \& Mcdermott, 1987) mengungkapkan bahwa masih banyak siswa mengalami kesulitan yang sangat besar dalam menerapkan materi usaha dan energi dalam kehidupan sehari-hari.

\section{KESIMPULAN}

Berdasarkan hasil penelitian survei dan pembahasan yang telah dilakukan bahwa keterampilan berpikir kritis mahasiswa yaitu pada komponen interpretation, analysis, inference, explanation, evaluation and self regulation masih dalam kategori sangat rendah. Hasil penelitian menunjukkan bahwa rata-rata skor keseluruhan dari tes yang telah dilakukan sebesar 37,1\%. Pada komponen analysis ini merupakan komponen dengan skor nilai paling rendah dari mahasiswa sebesar $22,5 \%$. Hal ini terlihat bahwa tingkat berpikir mahasiswa masih tergolong tingkat berpikir rendah terutama pada materi usaha dan energi. 


\section{DAFTAR PUSTAKA}

Anderson, L. W. \& Krathwohl, D. R (2001). A taxonomy for learning, teaching, andassessing: A revision of Bloom's taxonomy of educational objectives. New York: Longman

Demirhan, E., \& Köklükaya, A. N. (2013). The Critical Thinking Dispositions of Prospective Science Teachers. Procedia - Social and Behavioral Sciences, 116(2006), 1551-1555. https://doi.org/10.1016/j.sbspro.2014.01.433

Facione, P. A. (1990). Critical Thinking: A statement of expert consensus for purposes of educational assessment and instruction. Research findings and recommendations. American Philosophical Association.

Lawson, R. A., \& Mcdermott, L. C. (1987). Student understanding of the work energy and impulsemomentum theorems. American Journal of Physics, 811. https://doi.org/10.1119/1.14994

Manjarres, D. A., Herrera, W. J., Diaz, R. A., Manjarres, D. A., Herrera, W. J., \& Diaz, R. A. (2013). Work and energy in rotating systems. American Journal of Physics, 597. https://doi.org/10.1119/1.4807897

Pellegrino, J. W. (2017). Teaching, learning and assessing 21st century skills. Pedagogical Knowledge and the Changing Nature of the Teaching Profession. https://doi.org/10.1787/9789264270695-en

Rahayu. (2014). Analisis penyajian panduan pembelajaran literasi sains dalam buku guru tematik terpadu kelas IV SD/MI Kurikulum 2013. Bandung: Universitas Pendidikan Indonesia

Rahmatina, D. I., Sutopo, \& Wartono. (2017). Pemahaman Konsep dan Kemampuan Multirepresentasi Siswa SMA pada materi Usaha dan Energi. Prosiding Seminar Pendidikan IPA Pascasarjana UM, 2, 127-133.

Trianto. 2010. Model Pembelajaran Terpadu: Konsep, Strategi, dan Implementasinya dalam KTSP. Jakarta: Bumi Aksara

Winarti. (2015). Mahasiswadalam Mengerjakan Soal Konsep Kalor. Jurnal Inovasi Dan Pembelajaran Fisika, 2, 19-24. 